\title{
UJI PROTEKSI KOMBINASI ANTIOKSIDAN ASAM ASKORBAT DAN Na2EDTA SEBAGAI PENGKELAT Pb DARAH TERHADAP KADAR HEMOGLOBIN TIKUS (Mus musculus)
}

\section{PROTECTION TEST COMBINATIONS OF ANTIOXIDANTS ASCORBIC ACID AND Na2EDTA AS BRACING Pb BLOOD TOWARD HAEMOGLOBIN LEVELS OF MICE (Mus musculus)}

\author{
Sarno Setiawan*, Irawan, Alfath Fanidya \\ Universitas Negeri Semarang \\ Semarang, Jawa Tengah, Indonesia \\ *email korespondensi: sarno.setiawan19@gmail.com
}

\begin{abstract}
Abstrak
Penelitian ini bertujuan untuk menganalisis tingkat proteksi antioksidan kombinasi $\mathrm{Na}_{2} \mathrm{EDTA}_{\mathrm{A}}$ dan asam askorbat terhadap kadar hemoglobin tikus putih yang dipapar timbal asetat. Jumlah perlakuan dibagi menjadi 6 kelompok. Setiap kelompok perlakuan dipapar Pb asetat $175 \mathrm{mg} / \mathrm{kg}$ bb kecuali kelompok kontrol. Pada kelompok I diberikan $\mathrm{Na}_{2}$ EDTA $150 \mathrm{mg} / \mathrm{kg}$ bb, kelompok II $\mathrm{Na}_{2}$ EDTA 250 $\mathrm{mg} / \mathrm{kg}$ bb, kelompok III Na${ }_{2}$ EDTA $150 \mathrm{mg} / \mathrm{kg}$ bb dan asam askorbat $300 \mathrm{mg} / \mathrm{kg}$ bb, dan kelompok IV $\mathrm{Na}_{2}$ EDTA $250 \mathrm{mg} / \mathrm{kg}$ bb dan asam askorbat $500 \mathrm{mg} / \mathrm{kg}$ bb. Hasil yang diperoleh menunjukkan bahwa kelompok kontrol memiliki kadar hemoglobin tertinggi yaitu 13,1 g/100 mL, sedangkan kelompok kontrol negatif yaitu 6,3 g/100 mL, kelompok I yaitu 7,2 g/100 mL, kelompok II yaitu 7,7 g/100 mL, kelompok III yaitu 9,3 g/100 mL, dan kelompok IV yaitu 8,3 g/100 mL. Data tersebut menunjukkan bahwa ada pengaruh asam askorbat dan $\mathrm{Na}_{2}$ EDTA dalam menormalkan kadar hemoglobin tikus putih. Kombinasi antioksidan paling efektif yaitu $300 \mathrm{mg} / \mathrm{kg}$ bb asam askorbat dengan $150 \mathrm{mg} / \mathrm{kg} \mathrm{bb}$ $\mathrm{Na}_{2}$ EDTA. Hasil ANOVA menunjukkan bahwa $\mathrm{f}$ hitung < $\mathrm{f}$ tabel, artinya ada pengaruh pemberian $\mathrm{Na}_{2}$ EDTA dan asam askorbat terhadap kadar hemoglobin tikus putih yang induksi timbal asetat secara oral. Peningkatan kadar hemoglobin darah tikus disebabkan oleh pengkhelatan logam $\mathrm{Pb}$, sehingga menurunkan gangguan pada proses sintesis heme.
\end{abstract}

Kata kunci: asam askorbat, hemoglobin, $\mathrm{Na}_{2} \mathrm{EDTA}, \mathrm{Pb}$ darah

\begin{abstract}
This study aimed to analyze the level of antioxidant protection in combination of $\mathrm{Na}_{2}$ EDTA and ascorbic acid to the hemoglobin levels of white rats exposed to lead acetate. The number of treatments was divided into 6 groups. Each treatment group was exposed to $\mathrm{Pb}$ acetate $175 \mathrm{mg} / \mathrm{kg}$ bw except the control group. The group I was given $\mathrm{Na}_{2}$ EDTA $150 \mathrm{mg} / \mathrm{kg}$ bw, group II $\mathrm{Na}_{2}$ EDTA 250 $\mathrm{mg} / \mathrm{kg}$ bw, group III Na $\mathrm{NDDT}_{2} 150 \mathrm{mg} / \mathrm{kg}$ bw and ascorbic acid $300 \mathrm{mg} / \mathrm{kg}$ bw, and group IV $\mathrm{Na}_{2}$ EDTA $250 \mathrm{mg} / \mathrm{kg}$ bw and ascorbic acid $500 \mathrm{mg} / \mathrm{kg}$ bw. The results showed the control group had the highest hemoglobin level of $13.1 \mathrm{~g} / 100 \mathrm{~mL}$, while the negative control group was $6.3 \mathrm{~g} / 100$ $\mathrm{mL}$, group I was $7.2 \mathrm{~g} / 100 \mathrm{~mL}$, group II was $7.7 \mathrm{~g} / 100 \mathrm{~mL}$, group III was $9.3 \mathrm{~g} / 100 \mathrm{~mL}$, and group IV was $8.3 \mathrm{~g} / 100 \mathrm{~mL}$. The data show that there is an effect of ascorbic acid and Na2EDTA in normalizing hemoglobin levels in white rats. The most effective combination of antioxidants is 300 $\mathrm{mg} / \mathrm{kg}$ bw ascorbic acid with $150 \mathrm{mg} / \mathrm{kg}$ bw Na${ }_{2}$ EDTA. The ANOVA results showed that $\mathrm{f}$ count $<\mathrm{f}$ table, that mean there was an effect of the administration of $\mathrm{Na}_{2}$ EDTA and ascorbic acid in the hemoglobin levels of white rats which induced lead acetate orally. Increased levels of hemoglobin in rat blood are caused by the bracing of $\mathrm{Pb}$ metal, so decreasing interference on the process of heme synthesis.
\end{abstract}

Keywords: ascorbic acid, haemoglobin, $\mathrm{Na}_{2}$ EDTA, Pb blood 


\section{PENDAHULUAN}

Senyawa timbal $(\mathrm{Pb})$ terutama Tetra Ethyl Lead (TEL), yang digunakan sebagai bahan aditif pada bensin, merupakan senyawa $\mathrm{Pb}$ yang paling toksik bagi manusia. Timbal dalam bentuk TEL mudah larut dalam lemak dan mudah berdifusi ke dalam jaringan lunak seperti hati dan ginjal serta ke dalam jaringan keras seperti tulang. Senyawa $\mathrm{Pb}$ yang masuk tubuh manusia lewat inhalasi, akan diabsorpsi paruparu sebesar $10-30 \%$ dan sekitar $90 \% \mathrm{~Pb}$ yang terbawa aliran darah akan berikatan dengan eritrosit (Suyono, 1995). Sifat timbal mudah berikatan dengan gugus sulfhidril (-SH) penyusun enzim dan molekul protein, sehingga dapat menimbulkan hambatan terhadap aktivitas enzim (Hernayanti dkk., 2015).

Logam $\mathrm{Pb}$ dapat berasal dari aktivitas di bidang industri, transportasi, pertambangan dan lain sebagainya. Logam ini dapat mencemari lingkungan tanah, air dan udara, serta dapat berdampak terhadap kesehatan. Batas toleransi $\mathrm{Pb}$ yang masuk ke dalam tubuh per minggu (provisional tolerable weekly intake/PTWI) adalah $50 \mu \mathrm{g} / \mathrm{kg}$ berat badan untuk dewasa dan $25 \mu \mathrm{g} / \mathrm{kg}$ berat badan untuk anak- anak. Berdasarkan standar WHO (2011), apabila kandungan $\mathrm{Pb}$ lebih dari $80 \mu \mathrm{g} / 100 \mathrm{~mL}$ dapat membahayakan kesehatan. Pada anak-anak, kadar yang diperkenankan oleh Centre for Disease Control (CDC) adalah $10 \mu \mathrm{g} / 100 \mathrm{~mL}$.

Logam $\mathrm{Pb}$ dapat masuk ke tubuh secara inhalasi. Efisiensi pejanan $\mathrm{Pb}$ secara inhalasi dapat meningkat jika ukuran partikel semakin kecil. Setelah masuk ke dalam tubuh, $\mathrm{Pb}$ anorganik dan organik akan terdistribusi pada jaringan lunak, susunan saraf pusat, dan jaringan tulang. Efek klinik utama $\mathrm{Pb}$ anorganik adalah defisit susunan saraf pusat, neuropati, periferal anemia, nefropati dan hipertensi sedangkan $\mathrm{Pb}$ organik adalah ensefalopati (Kosnet, 2012).

Dalam tubuh $\mathrm{Pb}$ bersifat akumulatif sehingga proses pengeksresiannya berjalan lambat. Proses ekskresi $\mathrm{Pb}$ berjalan melalui beberapa cara, diantaranya melalui ginjal dan saluran pencernaan. Ekskresi $\mathrm{Pb}$ melalui urine sebanyak $75-80 \%$, feses $15 \%$ dan lainnya melalui empedu, keringat, kuku dan rambut (Palar, 2008). Kadar $\mathrm{Pb}$ dalam tubuh yang melebihi batas normal dapat mengganggu kesehatan baik fisik maupun mental. Menurut Doloksaribu (2008), kerusakan ginjal dapat terjadi apabila terpapar $\mathrm{Pb} 40 \mu \mathrm{g} / \mathrm{dL}$, kerusakan saraf dan anemia apabila $\mathrm{Pb}$ darah $>60 \mu \mathrm{g} / \mathrm{dL}$, dan apabila kadar $\mathrm{Pb}$ darah $>150 \mu \mathrm{g} / \mathrm{dL}$ dapat menyebabkan ensefalopati, sakit kepala, konstisipasi, sakit perut, diare, dan anoreksia (Doloksaribu, 2008). Disisi lain, logam $\mathrm{Pb}$ juga menyebabkan timbulnya radikal bebas yang berbahaya bagi tubuh serta menurunkan kemampuan antioksidasi tubuh (Ostrovskaya dkk., 2011).

Penelitian Muliyadi dkk. (2015), menunjukkan bahwa adanya $\mathrm{Pb}$ dalam darah mempengaruhi kadar hemoglobin yaitu pada kelompok terpapar $\mathrm{Pb}$ 11,20 ppm memiliki kadar hemoglobin sebesar 12,97 $\mathrm{g} / \mathrm{dL}$ yang nilainya lebih rendah dibandingkan kelompok yang tidak terpapar yaitu $14,77 \mathrm{~g} / \mathrm{dL}$. Peningkatan kadar hemoglobin dapat dilakukan dengan pemberian antioksidan. Penelitian Eni dkk., (2018) menunjukkan bahwa pemberian kitosan $64 \mathrm{mg} / \mathrm{kg}$ BB dan asam askorbat 300 $\mathrm{mg} / \mathrm{kg} \quad \mathrm{BB}$ dapat meningkatkan kadar hemoglobin tikus yang dipapar timbal asetat 175 $\mathrm{mg} / \mathrm{kg}$ BB yaitu 14,336 $\mathrm{g} / \mathrm{dL}$ dibanding kelompok kontrol negatif.

Logam $\mathrm{Pb}$ mengganggu proses sintesis heme yaitu mengikat Fe yang dibutuhkan oleh hemoglobin, sehingga menurunkan kadar hemoglobin. Pemberian kitosan berfungsi untuk mengkhelat ion $\mathrm{Pb}^{2+}$ sedangkan asam askorbat berfungsi untuk mempercepat penyerapan $\mathrm{Fe}$ untuk sistesis heme (El-fattah dkk., 2013; Elmatris dkk., 2015). Namun efek sebagai khelator $\mathrm{Pb}^{2+}$ belum sepenuhnya maksimal, serta penggunaan asam askorbat sebagai pengobatan penyakit masih perlu diteliti kembali (Arifuddin dkk., 2016; Marianti dkk., 2017).

Senyawa EDTA (Ethylen Diamine Tetra Acetate) merupakan ligan polidentat yang dapat mengikat ion $\mathrm{Pb}$ pada enam situs yang berbeda, yaitu ion asetat dan atom nitrogen melalui ikatan kovalen koordinasi (Aziz dkk., 2015). Maka dari itu, penelitian ini dilakukan untuk menganalisis apakah kombinasi $\mathrm{Na}_{2}$ EDTA dan asam askorbat yang berfungsi sebagai pengkelat $\mathrm{Pb}$ dan antioksidan akan saling bersinergi meningkatkan sifat antioksidasi dan mengurangi dampak negatif dari $\mathrm{Pb}$ dalam tubuh, terutama terhadap kadar $\mathrm{Hb}$.

\section{METODE PENELITIAN}

Alat yang digunakan yaitu timbangan hewan, haemometer sahli, mikrohematokrit, dan sonde. Bahan yang digunakan yaitu tikus putih (Rattus noevegicus L.) strain wistar 18 ekor, larutan $\mathrm{Pb}$ asetat $175 \mathrm{mg} / \mathrm{kg}$, aquades, alkohol $70 \%$, larutan $\mathrm{HCl} 0,1 \mathrm{~N}$, larutan $\mathrm{Na}_{2}$ EDTA, dan asam askorbat dari vitacimin. 
Penelitian ini diawali dengan adaptasi tikus putih dengan lingkungan laboratorium selama 1 minggu. Pemberian perlakuan (induksi oral $175 \mathrm{mg} / \mathrm{kg} \mathrm{Pb}$ asetat) setelah adaptasi dilakukan pada kelompok perlakuan kecuali kelompok kontrol (KK). Pemberian zat pengkelat pada perlakuan 1 (P1) yaitu $\mathrm{Na}_{2}$ EDTA $150 \mathrm{mg} / \mathrm{kg}$ bb, perlakuan 2 (P2) yaitu $\mathrm{Na}_{2}$ EDTA $250 \mathrm{mg} / \mathrm{kg}$ bb, perlakuan 3 (P3) yaitu $\mathrm{Na}_{2}$ EDTA $150 \mathrm{mg} / \mathrm{kg}$ dan asam askorbat $300 \mathrm{mg} / \mathrm{kg}$, dan perlakuan 4 (P4) yaitu $\mathrm{Na}_{2}$ EDTA $250 \mathrm{mg} / \mathrm{kg}$ dan asam askorbat $500 \mathrm{mg} / \mathrm{kg}$. Setelah perlakuan selama 14 hari, darah tikus diambil melalui ekor dan dilakukan uji kadar $\mathrm{Hb}$. Tabung pengukur Haemometer diisi dengan $\mathrm{HCl} 0,1 \mathrm{~N}$ sampai angka 2 (garis pada tabung paling bawah). Darah diambil dengan cara menghisapnya melalui pipet kapiler sampai tepat pada garis, kemudian ditiupkan darah ke dalam tabung pengukur yang telah diisi $\mathrm{HCl} 0,1 \mathrm{~N}$ kemudian dicampur rata dan dibiarkan selama 3 menit. Selanjutnya aquades diteteskan dan diaduk perlahan sampai muncul warna coklat standar yang ada di sebelah kiri dan kanan tabung pengukur. Kadar $\mathrm{Hb}$ darah ditunjukkan oleh tinggi permukaan cairan dalam tabung pengukur yaitu dalam g\% (yaitu g $\mathrm{Hb}$ dalam $100 \mathrm{ml}$ darah) dan dalam $\%$ (persentase $\mathrm{Hb}$ yang dihitung dibandingkan dengan $\mathrm{Hb}$ normal).

\section{HASIL DAN PEMBAHASAN}

Pemberian paparan $\mathrm{Pb}$ asetat sebanyak $175 \mathrm{mg} / \mathrm{kg}$ BB selama 14 hari memberikan perbedaan kadar hemoglobin tikus putih setiap kelompok perlakuan. Kadar Hemoglobin tikus putih setelah pemaparan $\mathrm{Pb}$ asetat disajikan pada Gambar 1.

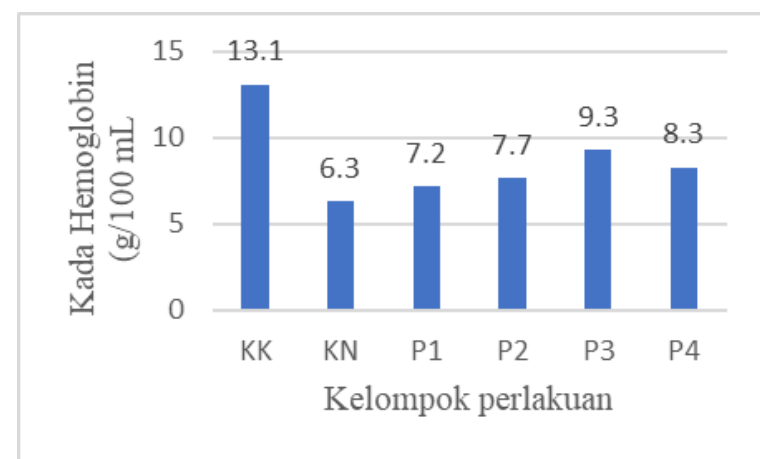

Gambar 1. Kadar Hb tikus putih setelah dipapar $\mathrm{Pb}$ asetat

$\mathrm{Pb}$ asetat menurunkan kadar $\mathrm{Hb}$ dalam darah tikus putih. Hal ini ditunjukkan dengan perbandingan nilai rata-rata dari kelompok kontrol dan kelompok perlakuan. Paparan $\mathrm{Pb}$ asetat secara terus menerus mengakibatkan timbal terakumulasi dalam darah dan terabsorbsi oleh tubuh, sehingga mempengaruhi oksigen yang terikat oleh hemoglobin.

Hasil analisis keempat kelompok perlakuan dengan menggunakan ANOVA dengan tingkat signifikansi 5\% menunjukkan bahwa $\mathrm{f}_{\text {hit }}<\mathrm{f}_{\text {tab }}$ sehingga ada pengaruh induksi $\mathrm{Pb}$ asetat terhadap penurunan kadar $\mathrm{Hb}$ tikus putih dan ada pengaruh kombinasi asam askorbat dan $\mathrm{Na}_{2}$ EDTA dalam menormalkan $\mathrm{Hb}$ darah.

Hasil pengukuran kadar hemoglobin tertinggi pada kelompok perlakuan 3 yaitu 9,3 $\mathrm{g} / 100 \mathrm{~mL}$. Hal ini menunjukkan bahwa pemberian $\mathrm{Na}_{2}$ EDTA $150 \mathrm{mg} / \mathrm{kg}$ bb dan asam askorbat $300 \mathrm{mg} / \mathrm{kg}$ mampu meningkatkan kadar hemoglobin terhadap kelompok kontrol negatif $(\mathrm{KN})$. Perbedaan muncul pada kelompok perlakuan 4 yang diperoleh kadar Hb sebesar 8,3 $\mathrm{g} / 100 \mathrm{~mL}$ dengan asam askorbat $500 \mathrm{~g} / 100 \mathrm{ml}$. Kadar $\mathrm{Hb}$ ini menurun sebesar $1 \mathrm{~g} / 100 \mathrm{~mL}$ dari kelompok perlakuan 3. Hal ini disebabkan oleh kemungkinan terjadi pengkhelatan lebih banyak terhadap logam $\mathrm{Fe}$ dibandingkan $\mathrm{Pb}$ oleh $\mathrm{Na}_{2}$ EDTA karena sifatnya yang tidak selektif dalam mengkhelat logam (Scott, 2004).

Tinggi rendahnya hemoglobin darah salah satunya dipengaruhi oleh asam askorbat) (Purwani dan Hadi, 2002). Asam askorbat berperan dalam metabolisme zat besi (mereduksi $\mathrm{Fe}$ dari bentuk $\mathrm{Fe}^{3+}$ menjadi $\mathrm{Fe}^{2+}$ yang lebih mudah diserap oleh sel mukosa usus. Selain itu, asam askorbat berperan dalam mobilisasi simpanan Fe terutama hemosiderin dalam limpa dan pemindahannya dalam darah. Jadi, adanya suplementasi asam askorbat akan mempercepat dan membantu penyerapan $\mathrm{Fe}$, sehingga kadar hemoglobin darah akan meningkat.

Absorpsi $\mathrm{Pb}$ menimbulkan efek subklinik karena sifat afinitas yang kuat. Efek subklinis yang ditimbulkan dapat terjadi pada sistem saraf, hematopoietik dan metabolisme pada sintesis heme, nukleotida, dan vitamin D. Efek utama $\mathrm{Pb}$ adalah mempengaruhi sintesis heme yang selanjutnya akan menyebabkan kerusakan pada darah. Berdasarkan penelitian yang dilakukan oleh Muliyadi dkk., (2015), menyatakan bahwa kandungan $\mathrm{Pb}$ dalam cat mempengaruhi kadar hemoglobin darah pekerja bagian pengecatan, setelah diteliti diperoleh bahwa kadar hemoglobinnya lebih rendah dibandingkan dengan pekerja bagian administrasi. Rata-rata kadar hemoglobin darah kelompok terpapar 12,97 g/dL, sedangkan pada 
kelompok tidak terpapar $14,77 \mathrm{~g} / \mathrm{dL}$ dan sebagian besar kadar hemoglobin darah kelompok terpapar kurang dari syarat hemoglobin darah normal yaitu 13,2-17,3 g/dL.

Mekanisme $\mathrm{Pb}$ dapat menurunkan kadar hemoglobin yaitu $\mathrm{Pb}$ dalam darah akan berikatan dengan eritrosit, sehingga dapat menghambat aktivitas enzim oksidase (Yulaipi, 2013). Adanya $\mathrm{Pb}$ dalam darah dapat mengikat ALAD (aminolevulenic acid dehidrase), suatu enzim yang diperlukan dalam metabolisme pembentukan sel darah merah dan membuangnya melalui urine. Itulah sebabnya semakin tinggi kadar $\mathrm{Pb}$ maka semakin tinggi pula kadar ALA dalam urine (ALA-U) dan semakin rendah ALAD dalam darah, sehingga banyaknya $\mathrm{Pb}$ darah adalah penyebab berkurangnya hemoglobin. Hal ini telah diteliti oleh Adnan (2001), bahwa kadar timbal dalam darah $10 \mu \mathrm{g} / \mathrm{dL}$ sudah dapat menyebabkan gangguan pada sintesis hemoglobin dengan penghambatan pada aktivitas enzim $\delta$ aminolevulinat dehidratase (ALAD). Hal ini mengakibatkan peningkatan kadar $\delta$ aminolevulinat ( $\delta$-ALA) dalam serum dan kemih.

Keberadaan $\mathrm{Pb}$ dalam tubuh dapat mengganggu sistem hemopoitik pada sintese heme melalui tiga mekanisme, yakni mengganggu penyatuan Glycine dan Succinyl Co-Enzyme A, melalui depresi terhadap deltaALAD, dan melalui gangguan terhadap enzim Ferrochelatase yang berfungsi melekatkan besi (Fe) terhadap protoporphyrin yang kemudian menjadi heme sebagai bagian dari hemoglobin (Malaka, 2012). Kombinasi asam askorbat dan EDTA sebagai antioksidan bekerja dengan mengkelat logam $\mathrm{Pb}$ dalam darah. Pada kelompok perlakuan yang diberi vitamin $\mathrm{C}$ dan EDTA terbukti dapat meningkatkan kadar $\mathrm{Hb}$ walaupun tikus terpapar $\mathrm{Pb}$.

Asam askorbat merupakan agen pereduksi (antioksidan) karena mendonorkan elektronnya, vitamin ini mencegah senyawa-senyawa lain agar tidak teroksidasi. Kadar asam askorbat di dalam tubuh memungkinkan untuk membentuk ion kompleks. Asam askorbat sendiri akan teroksidasi dalam proses antioksidan, sehingga menghasilkan asam dehidroaskorbat. Asam dehidroaskorbat dapat tereduksi kembali menjadi asam askorbat dengan bantuan enzim 4hidroksifenilpiruvat dioksigenase. Namun tidak semuanya dapat kembali menjadi asam askorbat lagi, karena di dalam tubuh manusia hanya terjadi secara parsial. Asam askorbat yang telah berubah menjadi ion kompleks berpotensi untuk menerima elektron dan direduksi oleh senyawa lain. Salah satunya direduksi melalui reaksi transisi yang diperantarai logam (misalnya ferrum atau cuprum). Disisi lain apabila $\mathrm{Pb}$ juga terdapat di dalam darah, maka ion kompleks asam askorbat juga akan mengkhelat $\mathrm{Pb}$. Hal ini ditunjukkan pada Gambar 2.

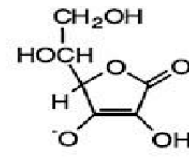

Ascorbate ( $\mathrm{AH}-)$

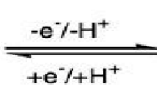

Ascorbyl Radical (A.-)

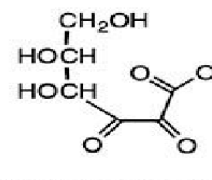

2,3-Diketogulonate

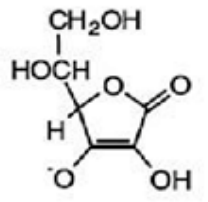

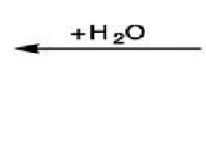

(a)

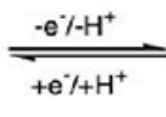

(b)
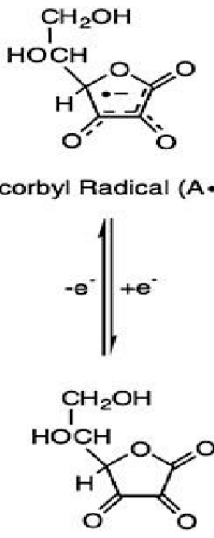

Dehydroascorbate

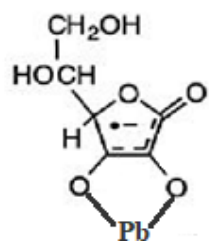

Gambar 2. (a) Pembentukan ion kompleks asam askorbat, (b) pengkhelatan $\mathrm{Pb}$ oleh asam askorbat

Hal ini mengakibatkan asam dehidroaskorbat meningkatkan persaingan antara $\mathrm{Pb}$ dan $\mathrm{Fe}$ di darah untuk dikhelat. Kemungkinan asam dehidroaskorbat lebih banyak mengkelat $\mathrm{Fe}$ daripada $\mathrm{Pb}$, sehingga asam dehidroaskorbat tidak signifikan dalam mengekhelat $\mathrm{Pb}$. Dampak yang ditimbulkan yaitu proses sintesis hemoglobin akan terganggu, sehingga terjadi penurunan kadar hemoglobin di dalam darah. Hal ini memungkinkan pada perlakuan 4 asam askorbat yang diberikan sebagian berubah menjadi ion kompleks, sehingga akan mengekhelat $\mathrm{Fe}$ dan $\mathrm{Pb}$ di dalam darah. Dampaknya kadar hemoglobin lebih rendah dibanding perlakuan 3 . Penelitian Purwani dan Hadi (2002), menunjukan bahwa pemberian vitamin $\mathrm{C}$ (asam askorbat) yang berlebih pada ikan juga dapat menjadikan defisiensi vitamin B12 karena vitamin $\mathrm{C}$ dapat mengubah sebagian vitamin B12 menjadi analognya, salah satu analognya adalah antivitamin B12, padahal vitamin B12 ini 
diperlukan dalam meningkatkan kadar hemoglobin.

\section{KESIMPULAN}

Berdasarkan hasil penelitian dan uji statistik yang telah dilakukan dapat disimpulkan bahwa induksi timbal asetat secara oral pada tikus berpengaruh terhadap jumlah kadar Hemoglobin ( $\mathrm{Hb})$. Kombinasi antioksidan yang paling optimal untuk mengkhelat $\mathrm{Pb}$ yaitu $\mathrm{Na}_{2}$ EDTA $150 \mathrm{mg} / \mathrm{kg}$ bb tikus dan asam askorbat $300 \mathrm{mg} / \mathrm{kg}$ BB dengan kadar $\mathrm{Hb}$ sebesar 9,3 g/100 mL.

\section{DAFTAR RUJUKAN}

Adnan, S. (2001). Pengaruh Pajanan Timbal terhadap Kesehatan dan Kualitas Semen Pekerja Laki-laki. Majalah Kedokteran Indonesia. 51(5): 168-174.

Anies. (2015). Penyakit Berbasis Lingkungan. :Berbagai Penyakit Menular dan Tidak Menular yang Disebabkan oleh Faktor Lingkungan. Cetakan 1. Yogyakarta: Arruzz Media.

Arifuddin, A., Asri., dan Elmatris. (2016). Efek Pemberian Vitamin C terhadap Gambaran Histopatologi Hati Tikus Wistar yang Terpapar Timbal Asetat. Jurnal Kesehatan Andalas. 5 (1).

Aziz, T., Amalia, R. P., dan Vishe, D. (2015). Removal Logam Berat dari Tanah Terkontaminasi dengan Menggunakan Chelating Agent (EDTA). Jurnal Teknik Kimia. 2(1): 41-49.

Doloksabiru, B. (2008). Pengaruh Proteksi Vitamin C Terhadap Kadar Ureum Kreatinin, dan Gambaran Histopatologis Ginjal Mencit yang Dipapar Plumbun. Tesis. Medan: Universitas Sumatra Utara.

El-fattah, H. M. A., El-rahman, M. K. A., dan Hassan, L. E. (2013). Chitosan as a hepato-protective agent against single oral dose of dioxin. IOSR J Environ Sci Toxicol Food Technol. 7(3): 11-17.

Elmatris, S., Husnii, K., dan Eti, Y. (2015). Efek Pemberian Vitamin C terhadap Aktivitas Katalase Hati Tikus Galur yang Terpapar Ion Pb. Jurnal Kesehatan Masyarakat. 4(1): 279-285.

Eni, W. N., Aditya, M., dan Wiwi, I. (2018). Bioaplikasi Kitosan dan Vitamin C terhadap Kadar Hemoglobin Rattus norvegicus. Life Science Journal of Biology. 7(2): 65-72.
Flora, S. J. S., Mehta A., dan Satsangi, K. (2003). Aluminum-induced oxidative stress in rat brain: response to combined administration of citric acid and HEDTA. Comparative Biochemistry and Physiology Part C: Toxicology \& Pharmacology, 134(3), 319-328.

Hernayanti., Agung, S., Dwi, L., dan Saefuddin, A. (2015). Efek Polimerase GENA GSTP-1 Terhadap Aktivitas Glutation S-Transferase (GST) Pada Individu terpapar Logam Berat Timbal. J. Manusia dan Lingkungan. 22(3): 305309.

Kosnet, M. J. (2012). Heavy Metals Intoxication and Chelators (Chapter 57). Basic and Clinical Pharmacology. 12t edition. Editor Katzung, B,G. Masters, SB., Trevor, AJ.. Mc GrawHill Companies Inc.

Malaka, I. (2012). Hubungan Kadar Timbel dalam Darah dengan Kadar Hemoglobin dan Hematokrit pada Petugas Pintu Tol Jagorawi. Jurnal Kesehatan Masyarakat. $6(1)$.

Marianti, A., Anatiasara, D., dan Ashar, F. F. (2017). Chitosan as Chelating and Protective Agents from Lead Intoxication in Rat. Biosaintifika. 9(1): 126-133.

Muliyadi., H. J. Mukono., dan Haryanto N. (2015). Paparan Timbal Udara Terhadap Timbal Darah, Hemoglobin, Cystatin C Serum Pekerja Pengecatan Mobil. Jurnal Kesehatan Masyarakat. 11(1): 87-95.

Ostrovskaya, S. S., Shatornaya V. F., dan Kolosova, I. (2011). Combined Impact of Plumbum and Cadmium on the Organism. Foreigning Literature Review 2(1): 99-101.

Palar, H. (2008). Pencemaran \& Toksikologi Logam Berat. Jakarta: Rineka Cipta.

Purwani, R. D., dan Hadi, H. (2002). Pengaruh Pemberian Pil Besi Folat dan Pil Vitamin C terhadap Perubahan Kadar Hemoglobin Anak Sekolah Dasar yang Anemia di Desa Nelayan Kabupaten Rembang. Jurnal Kedokteran Yarsi, 10, 8-15.

Scott, A. S. (2004). EDTA- a Molecule with a Complex Story. Molecule of the Month.

Suyono, J. (2015). Deteksi Dini Penyakit Akibat Kerja (World Health Organization). Editor: Caroline Wijaya. Jakarta: EGC Penerbit Buku Kedokteran. 
12 | Jurnal Zarah, Vol. 7 No. 1 (2019)

WHO (World Health Organisation). (2011). Lead in Drinking-water. Background document for development of WHO Guidelines for Drinking-water Quality.

Yulaipi, A. (2013). Bioakumulasi Logam Berat Timbal $(\mathrm{Pb})$ dan hubungannya dengan Laju Pertumbuhan Ikan mujair (Oreochromis mossambicus). Jurnal Sains dan Semi Pormits. 2(2): 23373520 . 